\title{
Factors Affecting Organizational Life Cycle and Faculty Performance in Higher Educational Institutes in NCR
}

\author{
Vipin Jain, Vibhor Jain, Deepti Gupta, Rachit Agarwal, Chanchal Chawla
}

\begin{abstract}
The practice of learning is considered to be important for an institution to survive or stay competitive when we are in the domain of business and management. Organizational life cycle $(O L C)$ theory, during an institution's growth from the beginning, to high growth leading to maturity, the institution's characteristics starts to differ and the internal resources and capabilities of an organization develop over a while. Several scholars have already had discussions about faculty performance in such an institution. Though, few of them talked over the issue in an educational context. The purpose of this paper is to contribute to the limited number of researches on the relationship between organizational life cycle \& faculty performance in a higher educational institute, by going through the impact of faculty participation in the performance of a private university in Delhi NCR. Organizational life cycle literature has discussed the dynamics, but there is very less knowledge about its relations with institution learning. This study's findings indicated that faculty performance is positively partial by employee's contribution in decision making and it significantly associates with academic results of the university. Additionally, employee participation is also positively linked with the academic grades of the university.
\end{abstract}

Keyword: higher education, public university, Organizational development, Organizational life cycle

\section{INTRODUCTION}

The organizational life cycle theory can be seen in various interesting ways as it uses a good description, commonly used for living entities, for clarifying the chronological phases of the firm progression and improvement. The narrative of these phases differ across various works of literature though, a common supposition is that they practice alterations frequently instigated by a crisis in the way of 'improvement'. Nonetheless, rapidly growing moderate-sized endeavours are no exclusions to these predicaments. In spite of their successes in accomplishing high progression, if they do not modify for limitations, they cannot maintain the progression rate that will sooner or later lead them to collapse. Therefore, to identify the present life cycle phase of an association is very essential for both the administration and forthcoming ideas. It

Revised Manuscript Received on October 22, 2019.

Dr. Vipin Jain, Professor and Principal, Teerthanker Mahaveer University, Moradabad. vipin555@ rediffmail.com

Dr. Vibhor Jain, Associate Professor , Teerthanker Mahaveer University, Moradabad, vibhorjain7@gmail.com

Dr. Deepti Gupta, Principal, Shree Satya College of Higher Education, Moradabad,drdeepti1993@gmail.com

Dr. Rachit Agarwal, Director, United Resourcing Services Pvt Ltd. New Delhi.rachit@urservices.org

Dr. Chanchal Chawla, Associate Professor, Teerthanker Mahaveer University, Moradabad

chanchalchawla0@gmail.com is necessary that they identify their proficiencies as well as restrains to triumph over the on the rise pains in the future. Certainly, higher education institutions have long been regarded as centres of knowledge creation and application for the larger society, but not only as learning organizations developing and transferring knowledge for the improvement of their basic processes. In their competitive environment throughout the world, universities should be given the incentives to become active learning organizations or promote learning activities at an organizational level to enhance the quality of teaching and doing research and getting sustainably developed.

Thus, this research aims to analyse the faculty Performance in higher education institutions and clarify its antecedents and consequences. First, we consider faculty Performance as a process to analyse how the organizations promote learning. We then propose and test several hypotheses about its' role as the mediator of faculty participation in decision-making and academic results using data collected from 100 employees in a public university in Delhi NCR. Finally, our findings and the implications for further study are discussed.

\section{BACK GROUND AND THEORETICAL PART OF FRAMEWORK}

\section{A. The Stages of Organizational Life Cycle}

a) The Birth: The initial stage is called Birth when the company is trying to be plausible and possible. There are two things about a young company first is that its structure is simple and informal and second is that it is managed by its owners, both of which are considered to be the main features of a company. At the time of the birth of a new company, high levels of creativity are needed to combine the scattered thoughts and build something from scratch. During this stage the company is obligated to practice responsibly otherwise, it would not get a head start. In this step, the company mainly focuses on building the stage of product innovation, providing amazing services to their clients as they have a limited market scope, creating an informal organizational structure and using certain raw information for decision-making and finding simpler solutions.

b) Growth phase- Growth stage, in this stage the expectancy from the company is to be successful as to establish its sectors by increasing the production of differentiated skills. 
If the idea of the creation and growth of the organization does not work, then optionally the criteria at the stage of rapid growth is determined which in this stage means that the system provides a chance to produce new ideas and cultivate creativity which leads to the rapid growth of fund investment.

c) Adulthood - A company reaches at the stage of adulthood by maintaining the level of sales, decreased the level of innovation and making more administrative organizational structure. At this point, the goals are homogeneous and efficient. New professional managers to create and arm the organization with new systems are hired. At this stage, the level of innovation is kept low since the company is already working on the existing projects. Adulthood is a stage when the stake of ownerships redistribution is high and the shareholder dividends are worth more to consider.

d) Reduction Stage- At this stage the elaborate stage structure is reborn. The product and market are varied to extend the company market structure part to accommodate more homogeneous and more complex markets in the future. More complex control and planning systems are prominent areas of focus. To maintain the hold on the market, innovation is a key aspect to create new products and seize new companies. To be able to implement new ideas for an organization, it is essential to have a presence of executive power in the organization at this stage. At this stage, the presence of executive power in the organization is essential that the organization can birth ideas to implement.

e) The Decline-In the final stage dissolution takes place when the market is inactive and stagnant, due to reduced innovation there is lack of earnings and a lot of external changes which leads to the fall of the company. In the initial stage of aristocracy and bureaucracy with the the weakening of executive power, a negative bureaucratic organization with a full and complete bureaucracy, only to follow the administrative system is created and the system has become many subsystems and maximum distance from the environment arises.

\section{B) Faculty Performance in a higher educational institute}

This study provides significant hand-outs. Nothing like most former studies scrutinizing the research and/educational connection, it thinks through the role of a performance assessment organisation in providing encouragements and inspirations for academics. It contests the predictable intelligence that research activity enables teaching efficiency with a finding that only high-quality research improves teaching quality. The performance capacities may be unfavourable to quality teaching are low-priced based on the finding that superior research is similar to quality teaching. Following the introduction, up to date performance evaluation trends in academia are outlined.

\section{Objective of study}

1. To study the Parameters which are affecting the organizational life cycle in higher education.

2. To analyze the Parameters which are affecting faculty performance in higher education

\section{Hypotheses}

H0: There is the significant result are affecting the organizational life cycle in higher education.

H1: There is significant results are affecting faculty performance in higher education.

\section{RESEARCH METHODOLOGY}

The researchers have attempted to try to approve this conviction. Hence, the principle of this research was to find the descriptive study between organization life cycle and Faculty Performance practices of the higher education in the public university of the region NCR Delhi.

The subject is chosen after thorough exercise of perusing different Journals, Online Articles and News, the reaction from employees working in the institute.

Design/methodology/approach - The research was designed out with the help of the Questionnaire for Employees working in private university and higher education institute in Moradabad city.

The sample size of respondents for data collection was 100 from different OLC of the age group 25-60 years. The technique used for carrying out the research was mean score and rank by Likert scale.

Primary- The data was collected from the faculties working in private universities and Higher Education Institute in NCR Delhi by a pre-designed Questionnaire.

Secondary - The data was collected from Journals, Articles and online sources.

\section{Data Collection}

The primary data was collected from the faculties working in private universities and Higher Education Institute in NCR Delhi by a pre-designed Questionnaire.

The secondary data was collected from Journals, Articles and online sources. The sample for the current study demonstrates the following respondents under study. We chose Organisational Life Cycle parameters variable \& faculty performance variable.

Table A) Parameters measured variable model of the organizational life cycle

\begin{tabular}{|l|l|l|l|l|l|l|l|}
\hline $\begin{array}{l}\text { Sr. } \\
\text { No } \\
\text {. }\end{array}$ & $\begin{array}{l}\text { Parameter affectin } \\
\text { g OLC of Higher } \\
\text { Education }\end{array}$ & $\begin{array}{l}\text { Total } \\
\text { respondent } \\
\text { s }\end{array}$ & $\begin{array}{l}\text { Strongl } \\
\text { y agree }\end{array}$ & $\begin{array}{l}\text { Agre } \\
\text { e }\end{array}$ & $\begin{array}{l}\text { Neutra } \\
\text { l }\end{array}$ & $\begin{array}{l}\text { Strongl } \\
\text { y } \\
\text { disagree }\end{array}$ & $\begin{array}{l}\text { Disagre } \\
\text { e }\end{array}$ \\
\hline l. & Continuous learning & 97 & 48 & 22 & 10 & 8 & 9 \\
\hline 2. & Research activities & 95 & 28 & 15 & 8 & 40 & 4 \\
\hline 3. & $\begin{array}{l}\text { Student development } \\
\text { targets }\end{array}$ & 93 & 52 & 18 & 4 & 9 & 10 \\
\hline 4. & $\begin{array}{l}\text { Curriculum planning } \\
\text { 5. }\end{array}$ & 92 & 50 & 20 & 3 & 9 & 10 \\
\hline 6. & $\begin{array}{l}\text { Collaboration \& Self } \\
\text { Protection }\end{array}$ & 85 & 32 & 22 & 5 & 18 & 8 \\
\hline
\end{tabular}


Table A) Parameters measured variable model of the organizational life cycle

Table: 1(B) Average Agreement at Each Level Regarding Organisational Life Cycle

\begin{tabular}{|l|l|l|l|}
\hline $\begin{array}{l}\text { Sr. } \\
\text { No. }\end{array}$ & $\begin{array}{l}\text { Parameter affecting } \\
\text { OLC of Higher } \\
\text { Education }\end{array}$ & $\begin{array}{l}\text { Total } \\
\text { respondents }\end{array}$ & Rank \\
\hline l. & Continuous learning & 97 & 2.05 \\
\hline 2. & Research activities & 95 & 2.75 \\
\hline 3. & $\begin{array}{l}\text { Student development } \\
\text { targets }\end{array}$ & 93 & 2.00 \\
\hline 4. & Curriculum planning & 92 & 2.01 \\
\hline $\mathbf{5 .}$ & Innovation activities & 98 & 1.90 \\
\hline 6. & $\begin{array}{l}\text { Collaboration \& Self } \\
\text { Protection }\end{array}$ & 85 & 2.38 \\
\hline
\end{tabular}

It is mentioned in Table 1(A) and Table1 (B) that the most noteworthy factor ensures research activity. It suggests that Suitable research activities are necessary for organisation growth and faculty development. From the table, the researcher gets the highest rank estimated as 2.75 on the liker scale which implies that the respondents. Thus with different variables like Innovation activities likewise getting lowest rank 1.90 dimensions of Weakness of Organisation This suggests that if an organisation can organisation life cycle easily they are happy to work in present organizations.

Firstly Researcher solved mean 2.18 after than standard deviation 0.2948 and calculates on $5 \%$ test of significance solved value of t-test for $9 \mathrm{df}$ status is 2.190 which is not very less than its table value so the difference between OLC and higher education is not comparable. Thus, $\mathrm{H} 0$ is right.

Table: 2(A) Percentage of involvement in teaching activities

\begin{tabular}{|c|c|c|c|c|c|c|c|}
\hline $\begin{array}{l}\text { Fr. } \\
\text { No. }\end{array}$ & $\begin{array}{l}\text { Parameter affecting } \\
\text { in faculty } \\
\text { performance }\end{array}$ & $\begin{array}{l}\text { Total } \\
\text { respondents }\end{array}$ & $\begin{array}{l}\text { Strongly } \\
\text { agree }\end{array}$ & Agree & Neutral & $\begin{array}{l}\text { Strongly } \\
\text { disagree }\end{array}$ & Disagree \\
\hline 1. & Updating courses & 85 & 35 & 22 & 16 & 10 & 2 \\
\hline 2. & $\begin{array}{l}\text { Increasing my } \\
\text { knowledge base }\end{array}$ & 94 & 48 & 25 & 8 & 10 & 3 \\
\hline 3. & $\begin{array}{ll}\begin{array}{l}\text { Planning } \\
\text { instruction }\end{array} & \text { course } \\
\end{array}$ & 86 & 22 & 38 & 20 & 3 & 3 \\
\hline 4. & $\begin{array}{l}\text { Creating syllabi for } \\
\text { courses }\end{array}$ & 80 & 28 & 25 & 21 & 2 & 4 \\
\hline 5. & $\begin{array}{l}\text { Assessment \& \& } \\
\text { feedback to students }\end{array}$ & 90 & 30 & 20 & 10 & 20 & 10 \\
\hline 6. & $\begin{array}{l}\text { Interaction with } \\
\text { students }\end{array}$ & 91 & 28 & 45 & 10 & 8 & 9 \\
\hline 7. & $\begin{array}{l}\text { Professional } \\
\text { development }\end{array}$ & 93 & 44 & 27 & 8 & 11 & 3 \\
\hline 8. & $\begin{array}{l}\text { Providing student } \\
\text { opportunities }\end{array}$ & 86 & 22 & 38 & 20 & 3 & 3 \\
\hline 9. & $\begin{array}{l}\text { Assisting with student } \\
\text { research }\end{array}$ & 88 & 38 & 24 & 20 & 2 & 4 \\
\hline 10. & $\begin{array}{l}\text { Comprehensive } \\
\text { exams }\end{array}$ & 92 & 46 & 25 & 8 & 10 & 3 \\
\hline 11. & Department activities & 90 & 38 & 25 & 21 & 4 & 2 \\
\hline 12. & $\begin{array}{l}\text { Organising } \\
\text { workshops }\end{array}$ & 89 & 25 & 32 & 20 & 2 & 10 \\
\hline 13. & $\begin{array}{ll}\begin{array}{l}\text { New } \\
\text { development }\end{array} & \text { course } \\
\end{array}$ & 88 & 38 & 24 & 20 & 2 & 4 \\
\hline 14. & $\begin{array}{l}\text { Teach new course } \\
\text { preparation } \\
\text { moral values }\end{array}$ & 83 & 30 & 42 & 6 & 4 & 1 \\
\hline
\end{tabular}

Table: 2 (B) Average Agreements at Each Level Regarding Faculty Performance

\begin{tabular}{|c|c|c|c|}
\hline $\begin{array}{l}\text { Sr. } \\
\text { No. }\end{array}$ & $\begin{array}{l}\text { Parameter affecting in } \\
\text { faculty performance }\end{array}$ & $\begin{array}{l}\text { Total } \\
\text { respondents }\end{array}$ & Rank \\
\hline 1. & Updating courses & 85 & 2.08 \\
\hline 2. & $\begin{array}{l}\text { Increasing my knowledge } \\
\text { base }\end{array}$ & 94 & 1.88 \\
\hline 3. & $\begin{array}{ll}\text { Planning } & \text { course } \\
\text { instruction } & \end{array}$ & 86 & 2.15 \\
\hline 4. & $\begin{array}{l}\text { Creating syllabi for } \\
\text { courses }\end{array}$ & 80 & 2.11 \\
\hline 5. & $\begin{array}{l}\text { Assessment \& feedback } \\
\text { to students }\end{array}$ & 90 & 2.56 \\
\hline 6. & Interaction with students & 91 & 2.47 \\
\hline 7. & $\begin{array}{l}\text { Professional } \\
\text { development }\end{array}$ & 93 & 1.94 \\
\hline 8. & $\begin{array}{ll}\text { Providing } & \text { student } \\
\text { opportunities } & \end{array}$ & 86 & 2.15 \\
\hline 9. & $\begin{array}{l}\text { Assisting with student } \\
\text { research }\end{array}$ & 88 & 1.97 \\
\hline 10. & Comprehensive exams & 92 & 1.90 \\
\hline 11. & Department activities & 90 & 1.96 \\
\hline 12. & Organising workshops & 89 & 2.32 \\
\hline 13. & New course development & 88 & 1.97 \\
\hline 14. & $\begin{array}{l}\text { Teach new course } \\
\text { preparation with moral } \\
\text { values }\end{array}$ & 83 & 1.84 \\
\hline
\end{tabular}

It is mentioned in Table 2(C) and Table2 (D) that there are numerous pursuits and activities related to teaching. As described, professors with their tenure-track were asked to indicate whether they were engaged in various research activities. And, whether they had produced any study products characteristically measured as a sign of efficiency. Research undertakings often stated by faculty included engaging in academic professional improvement activities in Assessment \& feedback to students getting the highest rank 2.56 by the help of the Likert scale. Thus with different variables like Teach new course preparation with moral values likewise getting lowest rank 1.84 dimensions of Weakness of Faculty Performance.

Researcher solved mean 2.09 after than standard deviation 0.215 and calculates on $5 \%$ test of significance solved the value of t-test for $14 \mathrm{df}$ statuses is 14.38 , which is 2.2621 ess from table value. Thus the difference is not valuable and $\mathrm{H} 0$ is right.This suggests that if an organisation can work on these factors that can be easily faculty are happy to work in present organizations. 


\section{CONCLUSION}

The organizational life cycle process in higher education public and private universities has been explored and the influencing factors and its' consequences were described. Those results help understanding more about OLC theory in the higher education settings. Further researches could address weaknesses seen in this paper to study more on organizational life cycle and faculty performance in the larger context of private universities in NCR Delhi empirically testing its relationship with other antecedents and consequences. Added studies might discover dissimilarities in workload in faculties between departments as recommended and across different types of higher institute. It seems very important that as institutions are reshaped with innovation to match the challenges of greatly condensed state finance according to NACC evaluation that their professors be at the centre of those procedures of change. It does not make sense that expertise inherent in highly trained faculty of such universities is omitted from decision-making procedures in favour of state representatives and politically aware players who, no matter how fine intentioned, are grounding their pitches on a set of assumptions that are greatly inconsistent, and who have minute indulgent of the consequences to scholars' learning likely to be given free rein by ill-founded reforms. In this organization government should promote NACC evaluators for developing innovation activities in teaching methodology and also bring to teach new courses with moral values.

\section{REFERENCE}

1. Armin, M., Khairuzaman Wann Ismail, W., Zareha Abdul Rasid, S., \& Daverson Andrew Selemani, R. (2015). "The influence of human resource organization practices on performance". The TQM Journal, 26(2), 125142

2. Abdul Kadir, D. N., Isiaka, S. B., \& Adedoyin, S. I. (2013). "Effects of Strategic Performance Appraisal, Career Planning and Employee Involvement on Organizational Commitment: An Empirical Study". International Business Research, 5(4). DOI: 10.5539/ibr.v5n4p124

3. Elcacer, J., M. Gitleman, (2006) 'Patent certifications as a measure of knowledge flows: the influence of examiner citations' The Rev. Economic. Statist. 88(4) 774-779

4. Ajay K. Jain Ana Moreno, (2015), "Organizational learning, knowledge management practices and firm's performance", The Learning Organization, Vol. 22 Is 1 pp. 14 - 39

5. Argote, Linda, and Ella Miron-Spektor, 'Organizational learning: From experience to knowledge', Organization Science 22.5 (2011): 1123-1137.

6. Argiris, C. \& Schõn, D.A. (1978), 'Organizational Learning: A Theory of Action Perspective', MA: Addition-Wesley.

7. Aydin, Bulent, and Adnan Ceylan, (2009), 'Does organizational learning capacity impact on organizational effectiveness? Research analysis of the metal industry', Development and Learning in Organizations 23.3, 21-23.

8. Bapuji, H., \& Crossan, M. (2004). "From questions to answers: reviewing organizational learning research". Management Learning, 35 Nr. (4), 397-417.

9. Georgios, \& Chatzoglou, P., N. Theriou, (2014). "The impact of best HRM practices on performance - identifying enabling factors". Employee Relations, 36(5), 535-561

10. Goh, S. and Richards, G. (1997), "Benchmarking the learning capacity of organizations”, European Management Journal, Vol. 15 No. 5, pp. 575-583

11. Grant Harman, M. H., Pham Thanh Nghi. (2010). "Reforming Higher Education in Vietnam Challenges and Priorities". Higher Education Dynamics, Springer, 29.

12. Guţă, A. L. (2014). "Measuring organizational learning. Model testing in two Romanian universities". Management \& Marketing, 9(3), 253-282.
13. Nonaka, I. (1994), "A dynamic theory of organizational knowledge", Organizational Science, Vol. 5, February, pp. 14-37.

14. Limpibunterng, Tharinee, and Lalit M. Johri (2009) "Complementary role of organizational learning capability in new service development (NSD) process." Learning The organization, The 16.4: 326-348

15. Lawrence Kok, M. J. L., Pierre Joubert. (2014). "Employee Involvement in DecisionMaking: A Case at the One University of Technology in South Africa". Mediterranean Journal of Social Sciences, 5(27). 